\title{
Evaluation of Anti-Nutritional Factor Reduction Techniques for Triticale Improved Utilization System in Amhara Region
}

\author{
Ayalew Demissew ${ }^{1 *}$, Keber Temesgen ${ }^{2}$ and Ayenew Meresa ${ }^{3}$ \\ Amhara Regional Agricultural Research Institute, Bahir Dar Food Science and Postharvest Handling Research Center, Bahir Dar, Ethiopia
}

\begin{abstract}
Triticale is breed of wheat and rye and can grow in poor soil fertility. The nutritional quality of triticale is similar to that of wheat and rye. But the presence of anti-nutritional factors especially tannin and phytate reduce the nutrient utilization and/or food intake products when used as human foods. Anti-nutritional factors are chemical compounds synthesized in natural food and or feedstuffs by the normal metabolism of plant species or may be formed during heat/alkaline processing of foods. In this study, different anti-nutritional factor reduction techniques (malting and blanching) were evaluated and remarkable reduction in antinutritional factor was found. Finally, these techniques (malting and blanching) were demonstrated at triticale potential farmers of the Amhara region in Degadamot and Fareta district.
\end{abstract}

Keywords: Triticale; Anti-nutritional factor; Malting; Blanching; Tannin and phytate

\section{Introduction}

Triticale is a crop species resulting from a plant breeder across between wheat (triticum) and rye (secale). The nutritional quality of triticale is superior quality of both wheat and rye but the presence of high level of tannin and phytate reduce the bioavailability, digestibility and absorption the crops nutrient. Anti-nutritional factors are compounds which reduce the nutrient utilization and/or food intake of plants or plant products used as human foods or animal feeds and they play a vital role in determining the use of plants for humans. Antinutritional factors are chemical compounds synthesized in natural food and or feedstuffs by the normal metabolism of plant species or may be formed during heat/alkaline processing of foods. Common anti-nutritional factors found in triticale are phytate and tannin. Antinutrients factors have effective role in reducing the nutritive value of pearl millet due to their ability to bind macro nutrients and make them unavailable, plus reducing digestibility of starch, protein as well as minerals availability. Phytate has high density of negatively charged phosphate groups which can easily binned with minerals and also with protein and reduce the bioavailability and absorption of these nutrients in the food consumed [1].

Tannins are water soluble phenolic compounds which have an intension to bind with macronutrients like protein and carbohydrates resulting reversible and irreversible tannin-protein or carbohydrate complexes. Tannin in the food so easily reduce the bioavailability, digestibility and absorption of protein in the food consumed [2]. During processing of foods, protein sources are treated with heat, oxidizing agents (such as hydrogen peroxide), organic solvents, alkalis, and acids for a variety of reasons such as to sterilize/pasteurize; improve flavor, texture, and other functional properties; deactivate anti-nutritional factors; and prepare concentrated protein products [3].

Several methods have been employed to improve the nutritional quality of triticale. These processing technologies employed include milling, cooking, germination, decortications, fermentation, soaking and malting have been documented to be effective treatments to remove the anti-nutritional factors and enhanced nutritional value. However, such information's are still scanty in Triticale consumers of Ethiopia. Therefore, the study was focusing on:

1. Analyze the chemical composition of triticale.
2. Determine the anti-nutritional factors in triticale.

3. Investigate the effect of processing (blanching, soaking and malting)

Finally, these reduction techniques were demonstrated at farmers living in highland regions of Ethiopia to improve the nutritional status of the people that uses triticale crop as staple food.

\section{Objective of the study}

General objective: Generating information about the level of antinutritional factors in triticale so as to improve the nutritional status of and feeding habit of the community.

\section{Specific objectives:}

1.To evaluate the performance of anti-nutritional factor reduction techniques in triticale.

2.To demonstrate improved techniques in rural community for better utilization of triticale.

\section{Materials and Methods}

\section{Sample collection and preparation}

Triticale sample was collected from farmers at Farta and Degadamotworeda then it was also carefully cleaned so as to make the sample free of foreign material as well as broken and shrunken ones.

\section{Proximate composition analysis}

Moisture content: Moisture content of the sample was determined

*Corresponding author: Ayalew Demissew, Amhara Regional Agricultural Research Institute, Bahir Dar Food Science and Postharvest Handling Research Center, P.O. Box 794, Bahir Dar, Ethiopia, Tel: +251912604705; E-mail: ayalewdemissew@yahoo.com

Received June 12, 2017; Accepted July 03, 2017; Published July 10, 2017

Citation: Demissew A, Temesgen K, Meresa A (2017) Evaluation of Anti-Nutritional Factor Reduction Techniques for Triticale Improved Utilization System in Amhara Region. J Food Process Technol 8: 681. doi: 10.4172/2157-7110.1000681

Copyright: @ 2017 Demissew A, et al. This is an open-access article distributed under the terms of the Creative Commons Attribution License, which permits unrestricted use, distribution, and reproduction in any medium, provided the original author and source are credited. 
according to the standard official method of analysis [4]. The moisture content was calculated as follows:

$$
M C(\%)=\frac{\left(\mathrm{W}_{1}-\mathrm{W}_{2}\right)}{\mathrm{W}_{1}} \times 100
$$

Where,

$$
\begin{aligned}
& \mathrm{W}_{1}=\text { Original weight of sample and } \\
& \mathrm{W}_{2}=\text { Weight of dried sample }
\end{aligned}
$$

Total crude protein content: Protein was determined by the Kjeldahl method. All nitrogen is converted to ammonia by digestion with a mixture of concentrated sulfuric acid and concentrated orthophosphoric acid containing potassium sulfate as a boiling point raising agent and selenium as a catalyst. The ammonia released after alkalization with sodium hydroxide is steam distilled into boric acid and titrated with sulfuric acid.

Digestion: $0.5 \mathrm{~g}$ of samples (in triplicate) were taken in a Tecator tube and $6 \mathrm{ml}$ of acid mixture (5 parts of concentrated ortho-phosphoric acid and 100 parts of concentrated sulfuric acid) was added, mixed thoroughly and $3.5 \mathrm{ml}$ of $30 \%$ hydrogen peroxide was added step by step. As soon as the violent reaction had ceased, the tubes were shaken for five minutes and placed back into the rack. A $3.00 \mathrm{~g}$ of the catalyst mixture (ground $0.5 \mathrm{~g}$ of selenium metal with $100 \mathrm{~g}$ of potassium sulfate) was added into each tube, and allowed to stand for about 10 minutes before digestion. When the temperature of the digester reached $370^{\circ} \mathrm{C}$, the tubes were lowered into the digester. The digestion was continued until a clear solution was obtained, about $1 \mathrm{~h}$. The tubes in the rack was transferred into the fume hood for cooling, a $15 \mathrm{ml}$ of demonized water was added, and shaken to avoid precipitation of sulfate in the solution.

Distillation: A $250 \mathrm{ml}$ conical flask containing $25 \mathrm{ml}$ of the boric acid-indictor solution was placed under the condenser of the distiller with its tips immersed into the solution. The digested and diluted solution was transferred into the sample compartment of the distiller. The tubes were rinsed with two portions of about $5 \mathrm{ml}$ de-ionized water and the rinses were added into the solution. A $25 \mathrm{ml}$ of $40 \%$ sodium hydroxide solution was added into the compartment and washed down with a small amount of water, stoppered and the steam switched on. A $100-\mathrm{ml}$ solution of the sample was distilled, and then the receiver was lowered so that the tip of the condenser is above the surface of the distiller. The distillation was continued until a total volume of $150 \mathrm{ml}$ is collected. The tip was rinsed with a few milliliters of water before the receiver was removed.

Titration: The distilled solution was titrated with $0.1 \mathrm{~N}$ sulfuric acid to a reddish color.

mg nitrogen in the sample $=\mathrm{V} \times \mathrm{N} \times 14$

g nitrogen sample $/ 100 \mathrm{~g}$ sample $=\mathrm{mg}$ of nitrogen $\times 100 / \mathrm{mg}$ of the sample

Total nitrogen $(\%)=[(\mathrm{V}-\mathrm{Vb}) \times \mathrm{N} \times 14]$

Crude protein $(\%)=$ Total nitrogen $(\%) \times \mathrm{F}$

Where:

$\mathrm{V}=$ Volume of sulfuric acid consumed to neutralize the test material $(\mathrm{ml})$

$\mathrm{Vb}=$ Volume of the acid consumed to neutralize the blank

$\mathrm{F}=$ Conversion factor of total nitrogen to crude protein (6.25)

14=Equivalent weight of nitrogen

\section{$\mathrm{N}=$ Normality of standard sulfuric acid}

Ash determination: Ash of the samples was estimated according to the official methods of analysis [4]. Ash content was calculated using the formula:

$$
\operatorname{Ash}(\%)=\frac{\mathrm{W}_{2}}{\mathrm{~W}_{1}} \times 100
$$

Where,

$\mathrm{W}_{1}=$ Original weight of a sample and

$\mathrm{W}_{2}=$ Weight of sample after ignition

Determination of crude oil: Crude oil of pearl millet sample was determined using the official methods of analysis [4] the crude oil was estimated using Soxhlet extractor.

$C O(\%)=\frac{\mathrm{W}_{2}-\mathrm{W}_{1}}{S} \times 100$

Where:

$$
\begin{aligned}
& \mathrm{W}_{1}=\text { Weight of empty receiver } \\
& \mathrm{W}_{2}=\text { Weight of receiver+oil } \\
& \mathrm{S}=\text { Original weight of dried sample }
\end{aligned}
$$

Crude fiber determination: Crude fiber of the sample was estimated according to the method described by Soetan [3]. Two grams of defatted sample were digested in $200 \mathrm{ml}$ boiling $0.255 \mathrm{~N} \mathrm{H}_{2} \mathrm{SO}_{4}$ under reflux condenser, for 30 minutes. Then it is filtered under suction using a linen piece as filter medium. The residue was washed with hot water to remove any trace of acid. A second alkali digestion was done using $200 \mathrm{ml}$ boiling $0.344 \mathrm{~N} \mathrm{NaOH}$ for 30 minutes, and then similarly filtered as above. The residue was washed with hot water, dried at $105^{\circ} \mathrm{C}$ overnight and then reweighed. The (CF) was calculated as:

$$
C F(\%)=\frac{\mathrm{W}_{1}-\mathrm{W}_{2}}{S} \times 100
$$

Where,

$\mathrm{W}_{1}=$ Weight of sample before ignition

$\mathrm{W}_{2}=$ Weight of sample after ignition

$\mathrm{S}=$ Original weight of sample

Carbohydrates determination: Total carbohydrates of samples were calculated by subtracting the value of protein, oil, fiber, ash and moisture content from 100.

Total carbohydrates $(\%)=100-[\mathrm{CP} \%+\mathrm{CF} \%+\mathrm{CO} \%+\mathrm{ash} \%+\mathrm{MC} \%]$

\section{Anti-nutritional factor reduction techniques}

Malting: Triticale sample was soaked for 3 hours and allowed to malt for one, two and three days. Then it was sun dried up to moisture content of $12 \%$ to $14 \%$ moisture content. Finally, the tannin and phytate content were analyzed in each sample.

Blanching: Blanching was carried out at $80^{\circ} \mathrm{C}$ for 20 minutes, 40 minutes and 60 minutes. Then it was allowed to dry up to moisture content of $12 \%$ to $14 \%$. Finally, the tannin and phytate content were analyzed in each sample.

\section{Anti-nutritional content determination}

Determination of tannin content: Tannin content (TC) of triticale sample was estimated using modified Vanillin-HCL in methanol as 
described by Grewal and Jood [5]. About $0.2 \mathrm{~g}$ of ground sample was placed in $100 \mathrm{ml}$ conical flask. Ten milliliters of $1 \% \mathrm{HCL}$ in methanol (v/v.) were added. Then the flasks were mechanically shaken for 20 minutes and centrifuged at $2500 \mathrm{rpm}$ for 5 minutes. After that one milliliter of the supernatant was taken and pipetted into a test tube and 5 milliliters of vanalin- $\mathrm{HCl}$ reagent (mixing equal volume of $8 \%$ concentrated $\mathrm{HCl}$ in methanol and $1 \%$ vanillin in methanol) was added. The optical density was read using a colorimeter. At $500 \mathrm{~nm}$ after 20 minutes incubation at $30^{\circ} \mathrm{C}$, a blank sample was carried out with each run of samples. A standard curve was prepared expressing the result of tannic acid, i.e., amount of tannic $(\mathrm{mg} / \mathrm{ml})$ which gives color intensity equivalent to that given by tannin after correcting for blank. Tannin content (TC) was calculated from the following equation:

$$
T C(\%)=\frac{\mathrm{C} \times 10}{200} \times 100
$$

Where,

\section{$\mathrm{C}=$ Concentration corresponding to optical density}

$10=$ Volume of extract in $\mathrm{ml}$

\section{$200=$ Sample weight in $\mathrm{mg}$}

Determination of phytic acid content: Phytate of each sample was determined according to the method described by Grewal and Jood [5]. One gram of finely ground sample was weighed into a $125-\mathrm{ml}$ conical flask, extracted with $50 \mathrm{ml}$ 3\% TCA (W/V) for 3 hours with mechanical shaking. Then the suspension was centrifuged at $3000 \mathrm{rpm}$ for 10 minutes to 15 minutes. Ten milliliters of aliquots supernatant were transferred into a $50 \mathrm{ml}$ boiling tubes and then 4 milliliters of $\mathrm{FeCl}_{3}$ ( $2 \mathrm{mg}$ Ferriciron $\left(\mathrm{Fe}^{+3}\right)$ per $\mathrm{ml} \mathrm{3 \%} \mathrm{TCA),} \mathrm{were} \mathrm{added.} \mathrm{The} \mathrm{tube} \mathrm{was}$ heated in boiling water bath for 45 minutes and one or two drops of 3\% sodium sulphate $\left(\mathrm{Na}_{2} \mathrm{SO}_{4}\right)$ in $3 \%$ TCA were added. The tube was cooled and centrifuged at $3000 \mathrm{rpm}$ for 10 minutes to 15 minutes and the clear supernatant was decanted carefully. The precipitate was then washed twice by dispersing well into $25 \mathrm{ml} \mathrm{3 \%}$ TCA and heated in boiling water bath for 5 minutes to 10 minutes and centrifuged. The supernatant was decanted and then washed once with $25 \mathrm{ml}$ of distilled water.

The precipitate was cautiously dispersed in a few $\mathrm{ml}$ of distilled water enriched with $3 \mathrm{ml} 1.5 \mathrm{~N} \mathrm{NaOH}$ with mixing. The volume was made approximately to $30 \mathrm{ml}$ with distilled water and heated in boiling water bath for 30 minutes. The contents of the boiling tube were filtrate (hot filtered) through filter paper (Whatman No.1). The filtered was discarded and the precipitate was dissolved in $40 \mathrm{ml} 3.2 \mathrm{~N} \mathrm{HNO}_{3}$ (hot) into a $100-\mathrm{ml}$ volumetric flask. The precipitate was washed with distilled water. The flask contents were cooled to room temperature $\left(28^{\circ} \mathrm{C}\right.$ to $\left.32^{\circ} \mathrm{C}\right)$ and diluted to volume with distilled water. Then 0.5 $\mathrm{ml}$ was transferred to a gradual test tube, and $2 \mathrm{ml}$ of $1.5 \mathrm{M}$ potassium thiocyanate $(\mathrm{KSCN})$ were added and the volume was completed to 10 $\mathrm{ml}$ with distilled water. The density of color was read at $480 \mathrm{~nm}$ (within one minute) in spectrophotometer (corning, 259). A standard curve of different $\mathrm{Fe}\left(\mathrm{NO}_{3}\right)_{3}$ concentrations were plotted to calculate the ferric ion concentration. The phytate phosphorus was calculated from the ferric ion concentration assuming 4:6 (iron: phosphorus) molar ratio.

$$
\text { Phytate }(\mathrm{mg} / 100 \mathrm{~g})=\frac{6 / 4(A \times C \times 20 \times 10 \times 50)}{1000 \times S \times 100}
$$

Where,

$$
\begin{aligned}
& \text { A=Optical density } \\
& \text { C=Concentration corresponding to optical density } \\
& \text { S=Weight of sample }
\end{aligned}
$$

\section{Results and Discussion}

\section{Proximate composition}

In Ethiopian case triticale grain became important food grain in highland districts of the country and also there was also complain on the nutritional content of the crop by these communities. But the nutritional profile of the crop was somewhat similar as that of wheat. The proximate composition of triticale grain is determined and the result had been shown in the Table 1 below. The moisture content of triticale grains had slightly found to be $9.4 \%$ which was a little lower as it had been reported by Grewal and Jood [5]. The crude protein and oil content of triticale were found $14.64 \%$ and $1.08 \%$ respectively. In case of protein content, the result found was greater while the oil content was lowered than the report by Grewal and Jood [5] but in agreement with Lorenz [6] report. The total carbohydrate content of triticale was resulted as $71.15 \%$ while the total ash content was $1.97 \%$. In both total carbohydrate and ash content the result did not agree with the previous reports by Grewal and Jood [5]. The difference in proximate composition of triticale may arise from due to the variation in soil fertility and in general difference in agronomic practices.

\section{Tannin and phytate composition}

The perceptions of the highland triticale potential farmers as if triticale is inferior in quality than other cereals were more probably due the action of anti-nutritional factors. The tannin and phytate content of the triticale grain was shown in Table 2. The tannin and phytate content of triticale were found $285.56 \mathrm{mg} / 100 \mathrm{~g}$ and $221.97 \mathrm{mg} / 100$ $\mathrm{g}$ respectively. The concentrations of these anti-nutritional factors in triticale were enough to reduce the bioavailability and digestibility of nutrients when consumed by humans as food, although it is lower than that of pearl millet as reported by Elhage et al. [7].

\section{Effect of blanching on tannin content}

As it is seen the Figure 1 blanching reduces tannin content significantly $(\mathrm{p}<0.05)$. Tannin content of triticale reduced rapidly as the blanching temperature and time increase but the higher the blanching temperature and time the inferior the baking quality the crop. Blanching of triticale at $75^{\circ} \mathrm{C}$ for 20 minutes reduced tannin from $285.56 \mathrm{mg} / 100 \mathrm{~g}$ to $4.67 \mathrm{mg} / 100 \mathrm{~g}$ while the tannin content lowers from $285.56 \mathrm{mg} / 100 \mathrm{~g}$ to $7.08 \mathrm{mg} / 100 \mathrm{~g}$ during blanching of the crop at $55^{\circ} \mathrm{C}$ for 20 minutes.

\section{Effect of blanching on phytate content}

In the Figure 2 the phytate content of triticale sample was reduced significantly $(\mathrm{p}<0.05)$. In this all blanching process, the phytate content reduced significantly but in the case of blanching temperature $75^{\circ} \mathrm{C}$

\begin{tabular}{|c|c|}
\hline Nutrients & Values \\
\hline Moisture & $9.40 \%$ \\
\hline Crude protein & $14.64 \%$ \\
\hline Crude oil & $1.08 \%$ \\
\hline Total ash & $1.97 \%$ \\
\hline Total carbohydrate & $71.15 \%$ \\
\hline Crude fibre & $1.82 \%$ \\
\hline
\end{tabular}

Table 1: Proximate composition of triticale.

\begin{tabular}{|c|c|}
\hline Anti-nutritional factor & Amount \\
\hline Tannin & $285.56 \mathrm{mg} / 100 \mathrm{~g}$ \\
\hline Phytate & $221.97 \mathrm{mg} / 100 \mathrm{~g}$ \\
\hline
\end{tabular}

Table 2: Tannin and phytate content. 


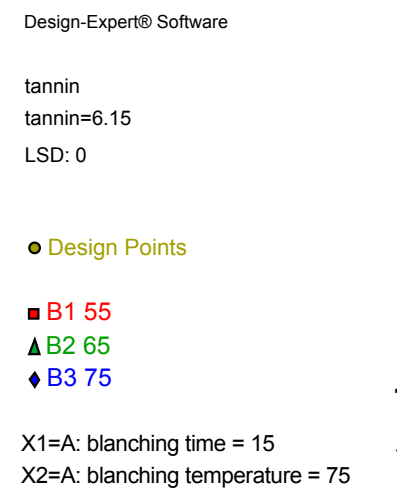

$\mathrm{X} 2=\mathrm{A}$ : blanching temperature $=75$

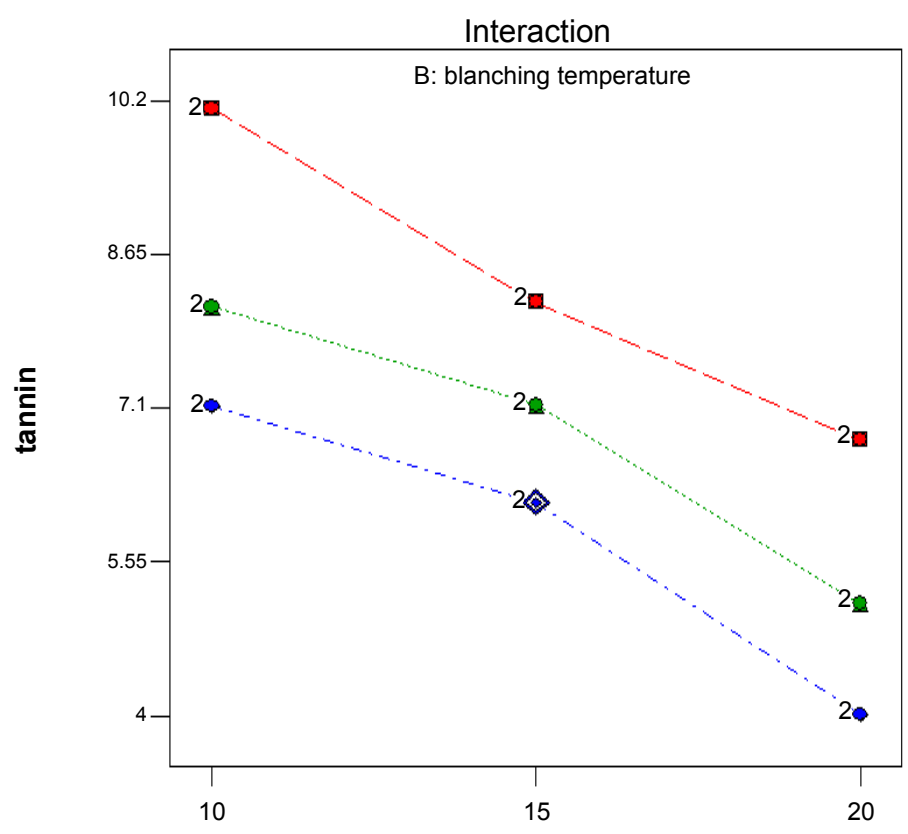

A: blanching time

- Blanching time is in minutes

- Blanching temperature is in ${ }^{\circ} \mathrm{C}$

- Tannin content is in $\mathrm{mg} / \mathrm{g}$

Figure 1: Effect of blanching on tannin content.

Design-Expert $\circledast$ Software

tannin

tannin $=7.09$

LSD: 0

- Design Points

$X 1=A$ : malting time $=2$

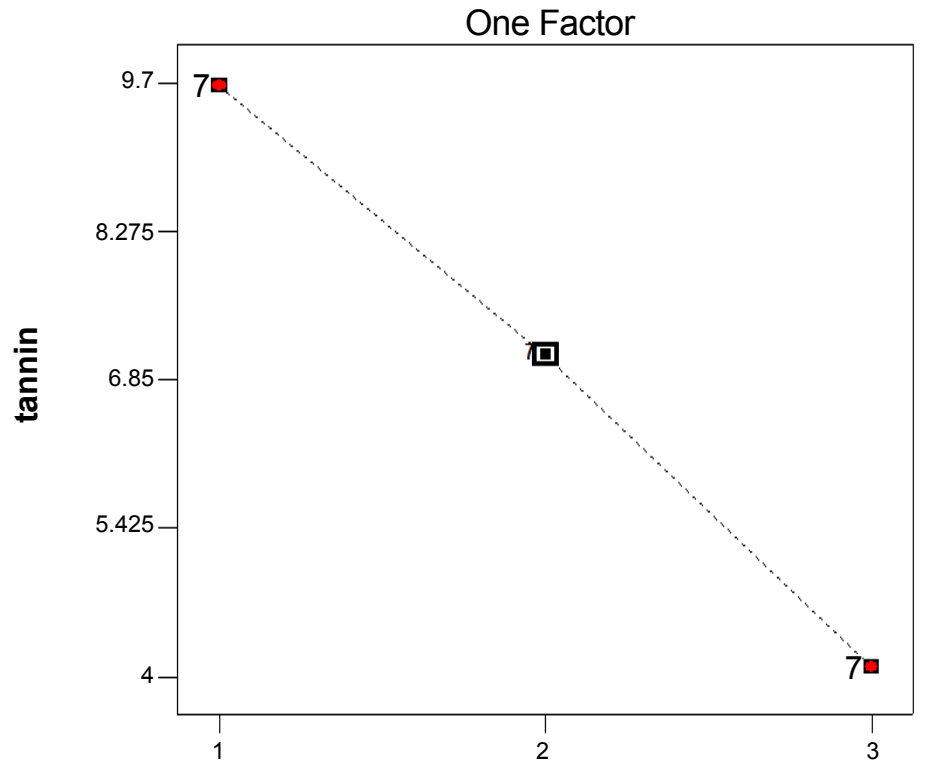

A: malting time

- Malting time is in days

- Tannin content is in $\mathrm{mg} / \mathrm{g}$

Figure 2: Effect of malting on tannin content. 


Design-Expert $\Theta$ Software
phytate
phytate $=101.12$
LSD: 0
- Design Points
$<1=$ A: malting time $=2$

- Phytate content is in $\mathrm{mg} / \mathrm{g}$

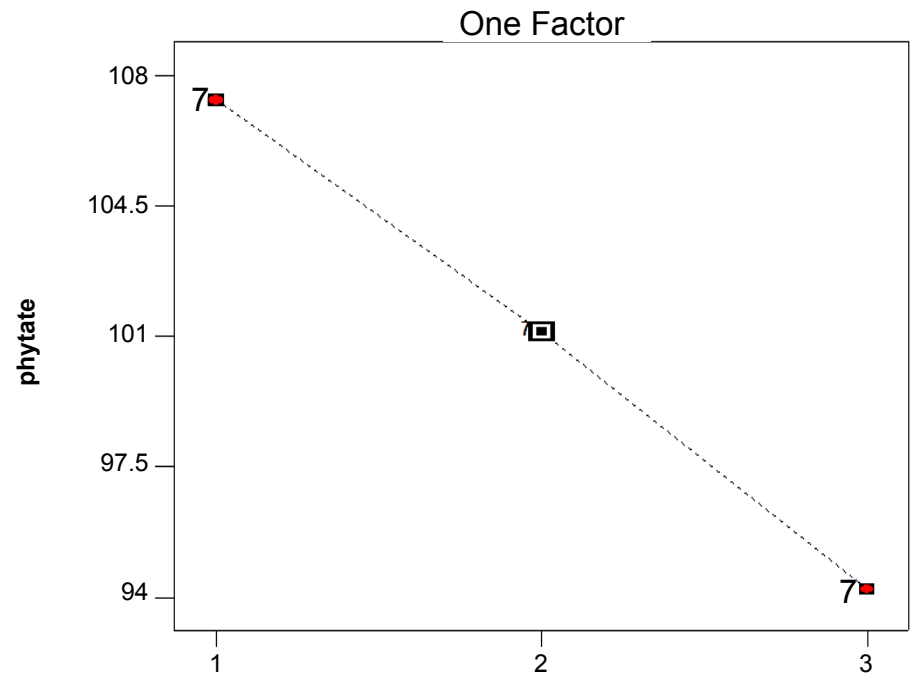

A: malting time

Figure 3: Effect of malting on phytate content.

and time 20 minutes maximum reduction of phytate recorded. At blanching temperature $75^{\circ} \mathrm{C}$ and time 20 minute the phytate content was reduced from $221.97 \mathrm{mg} / 100 \mathrm{~g}$ to $4.98 \mathrm{mg} / 100 \mathrm{~g}$.

\section{Effect of malting on tannin content}

As it is shown in Figure 2, malting reduces tannin content in triticale significantly at $(\mathrm{p}<0.05)$ as it did in millet as reported by Dhankher and Chauhan [8]. The greatest reduction was achieved at malting of the crop for three days. At this malting day, the baking quality crop reduces hence it became difficult to recommend at this reduction condition to the consumers. Malting of triticale for three days reduces tannin content from $285.56 \mathrm{mg} / 100 \mathrm{~g}$ to $3.98 \mathrm{mg} / 100 \mathrm{~g}$ while malting of one and two days reduce the content $7.34 \mathrm{mg} / 100 \mathrm{~g}$ and $9.7 \mathrm{mg} / 100 \mathrm{~g}$ respectively.

\section{Effect of malting on phytate content}

In Figure 3 it is indicated that the phytate content of triticale was reduced significantly at $(\mathrm{p}<0.05)$ during malting. In considering the case of malting for three days reduced phytate content from 221.97 $\mathrm{mg} / 100 \mathrm{~g}$ to $93.34 \mathrm{mg} / 100 \mathrm{~g}$. By contrasting the tannin content with phytate content reduction, phytate reduced to a lesser extent. The loss of phytic acid during germination may be caused by hydrolytic activity of the enzyme phytase. Similar losses of phytic acid during soaking and germination have been reported by Grewal and Jood [5].

\section{Conclusion and Recommendations}

Blanching and malting reduce tannin and phytate content significantly at $(\mathrm{p}<0.05)$. But in considering triticale malting reduces tannin and phytate to maximum extent than blanching techniques employed. For improved utilization of triticale employing these antinutritional factor reduction techniques (malting and blanching) would be mandatory to enhance the nutritional status of the society. Sensory attributes and baking quality of triticale food products were the criteria to select optimal malting and blanching parameters. For bakery products, the optimal blanching and malting were $75^{\circ} \mathrm{C}$ for 15 minutes and one day respectively but in case of weaning food preparation the recommended malting time is for three days.

\section{References}

1. Walter HL, Fanny C, Charles R, Christian (2002) Minerals and phytic acid interaction: Is it a real problem for human nutrition. Int J Food Sci Tech 37: 727-739.

2. Smitha PA, Alagundagi SC, Salakinkop SR (2013) The anti-nutritional factors in forages- A review. Current Biotica 6: 516-526.

3. Soetan KO, Oyewole OE (2009) The need for adequate processing to reduce the anti-nutritional factors in plants used as human foods and animal feeds: A review. Africa J Food Sci 3: 223-232.

4. AOAC (1984) Official methods of analysis. Association of Agricultural Chemists, Washington DC, USA.

5. Grewal A, Jood S (2006) Effect of processing treatments on nutritional and antinutritional contents on green gram. J Food Biochem 30: 535-546.

6. Lorenz K (1980) Cereal sprouts: Composition, nutritive value, food application CRC Review. J Food Sci Nutri 13: 353-385.

7. Elhage ME, Tinay AH, Yousif NE (2002) Effect of fermentation and dehulling on starch, total polyphenols, phytic acid content and in vitro protein digestibility of pearl millet. J Food Chem 77: 193- 196.

8. Dhankher N, Chauhan BM (1989) Effect of fermentation on $\mathrm{HCl}$ extractability of minerals in rabadi-An indigenous fermented food of India. J Sci Food Agric 49: $467-472$.

Citation: Demissew A, Temesgen K, Meresa A (2017) Evaluation of AntiNutritional Factor Reduction Techniques for Triticale Improved Utilization System in Amhara Region. J Food Process Technol 8: 681. doi: 10.4172/21577110.1000681 